\title{
Commentary: Trim the fat
}

\author{
Thomas E. MacGillivray, MD, and \\ Michael J. Reardon, MD
}

Primary cardiac tumors are rare, and most surgeons gain limited experience in their management. Most benign tumors such as myxoma and fibroelastoma can be surgically resected with excellent outcomes and minimal to no mortality. ${ }^{1}$ More complex benign tumors such as paraganglioma generally require more planning and experience for successful surgical resection. ${ }^{2}$ Malignant primary cardiac tumors are substantially more complex to evaluate and treat. The most common malignant primary cardiac tumor is sarcoma, and surgical resection has been associated with increased survival in this deadly disease. ${ }^{3}$ The second most common malignant primary cardiac tumor is lymphoma, and surgical resection has no survival advantage and should be avoided. ${ }^{4}$ Primary sarcomas without metastatic disease are best treated with complete surgical resection when anatomically and physiologically possible..$^{5}$ Even with excellent imaging, the anatomy may be challenging, and additional measures to fully understand the tumor anatomy and involved cardiac structures may be beneficial in complex tumors.

In this issue of the Journal, Kim and colleagues ${ }^{6}$ present an unusual large cardiac tumor penetrating the right ventricular wall and their approach to evaluation and treatment. Their patient was a 33-year-old woman who had a large cardiac tumor found incidentally on echocardiogram. There was no ventricular or valvular function impairment by the tumor. Computed tomography showed an epicardial-based tumor penetrating into the right ventricular wall on the

\footnotetext{
From the Department of Cardiovascular Surgery, Houston Methodist Hospital, Houston, Tex.

Disclosures: The authors reported no conflicts of interest.

The Journal policy requires editors and reviewers to disclose conflicts of interest and to decline handling or reviewing manuscripts for which they may have a conflict of interest. The editors and reviewers of this article have no conflicts of interest.

Received for publication Nov 2, 2021; revisions received Nov 2, 2021; accepted for publication Nov 5, 2021; available ahead of print Nov 11, 2021.

Address for reprints: Michael J. Reardon, MD, Department of Cardiovascular Surgery, Houston Methodist Hospital, 6550 Fannin, Suite 1401, Houston, TX 77030 (E-mail: mreardon@houstonmethodist.org).

JTCVS Techniques 2022;11:41-2

2666-2507

Copyright (c) 2021 The Author(s). Published by Elsevier Inc. on behalf of The American Association for Thoracic Surgery. This is an open access article under the CC BY license (http://creativecommons.org/licenses/by/4.0/).

https://doi.org/10.1016/j.xjtc.2021.11.008
}

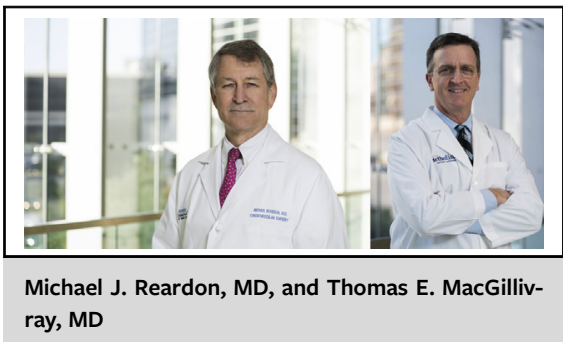

CENTRAL MESSAGE

Complex cardiac tumors present a challenge in evaluation and management. A multidisciplinary approach and proper use of imaging is imperative. 3-dimensional model use can be helpful in these cases

inferior surface of the heart. The working diagnosis was liposarcoma, and surgical resection was planned aided by the 3-dimensional printing of a model to allow advanced surgical consideration. The surgical procedure is nicely described in the text and well-illustrated in the companion video. The surgical pathology as well as the image of the tumor at surgery are both consistent with a cardiac lipoma, and the patient did well and should be cured. The authors are to be congratulated for this excellent outcome.

Despite this positive outcome for the patient, there are several points worth discussing about the case. Primary tumors of the heart believed to be malignant would be best managed in a center with a dedicated cardiac tumor team. ${ }^{7}$ We have employed a cardiac tumor team from MD Anderson Cancer Center and the Houston Methodist Hospital that meets monthly with a focus on complex and malignant primary cardiac tumors. This has led to an experience of surgical resection in 122 primary cardiac sarcomas. ${ }^{8}$ An advantage of a dedicated team is a more in-depth understanding of the needed imaging and its interpretation. One of the more common scenarios we are presented with is the incomplete resection of a left atrial sarcoma that was believed to be a large benign myxoma on image interpretation. Differentiating benign from malignant primary tumors requires multimodality imaging and in-depth knowledge of proper interpretation. ${ }^{9,10}$ Suspecting a primary cardiac tumor, especially when on the left side of the heart, to be malignant helps the surgeon plan for the advanced surgical 
techniques that may be necessary for complete surgical removal. ${ }^{11}$ In the case presented, a malignant liposarcoma was suspected and a benign lipoma was found. Although the patient did well, cardiac lipomas do not always need to be resected, and we have followed several without tumor growth or consequence. Cardiac magnetic resonance imaging is very helpful in this regard. Lipomas generally have homogenous high signal on T1 with complete suppression with fat saturation and no low signal on $\mathrm{T} 2$ with fat saturation. Liposarcomas tend to be larger, more irregular, and have a heterogenous signal on T2 with fat saturation. This of course is not always definitive, but it would be of interest to review the cardiac magnetic resonance imaging in this case. Finally, we fully agree with the authors that 3dimensional printing can be very useful in evaluating the surgical approach to complex tumors and have also previously used this to our benefit. ${ }^{12}$

We again congratulate the authors on an outstanding case and excellent result. Every addition to our knowledge base for complex primary cardiac tumors helps advance our field and benefit our patients.

\section{References}

1. Bakaeen FG, Reardon MJ, Coselli JS, Bakaeen FG, Reardon MJ, Coselli JS, et al. Surgical outcome in 85 patients with primary cardiac tumors. Am J Surg. 2003; 186:641-7; discussion 647 .
2. Chan EY, Ravi V, Ali A, Nguyen DT, Graviss EA, MacGillivray TE, et al. Surgical management of primary pulmonary artery sarcoma. Semin Thorac Cardiovasc Surg. November 4, 2021 [Epub ahead of print].

3. Yin K, Luo R, Wei Y, Yin K, Luo R, Wei Y, et al. Survival outcomes in patients with primary cardiac sarcoma in the United States. J Thorac Cardiovasc Surg. 2021;162:107-15.e102.

4. Yin K, Brydges H, Lawrence KW, Yin K, Brydges H, Lawrence KW, et al. Primary cardiac lymphoma. J Thorac Cardiovasc Surg. October 7, 2020 [Epub ahead of print].

5. Yanagawa B, Mazine A, Chan EY, Barker CM, Gritti M, Reul RM, et al. Surgery for tumors of the heart. Semin Thorac Cardiovasc Surg. 2018;30: 385-97.

6. Kim E, Pyo WK, Yang DH, Kim JB. Large primary cardiac tumor penetrating the right ventricular ventricle: 3 -dimension printing-based surgical planning. J Thorac Cardiovasc Surg Tech. 2022;11:37-40.

7. Lestuzzi C, Reardon MJ. Primary cardiac malignancies the need for a multidisciplinary approach and the role of the cardio-oncologist. J Am Coll Cardiol. 2020;75:2348-51.

8. Chan EY, Areeba Ali M, Mujeeb Zubair M, et al. Primary cardiac sarcomas: treatment strategies. J Thorac Cardiovasc Surg. 2022 [Epub ahead of print].

9. Kassi M, Polsani V, Schutt RC, Wong S, Nabi F, Reardon MJ, et al. Differentiating benign from malignant cardiac tumors with cardiac magnetic resonance imaging. J Thorac Cardiovasc Surg. 2019;157: 1912-22.e1912.

10. Shenoy C, Grizzard JD, Shah DJ, Kassi M, Reardon MJ, Zagurovskaya M, et al. Cardiovascular magnetic resonance imaging in suspected cardiac tumour: a multicentre outcomes study. Eur Heart J. 2021; ehab635.

11. MacGillivray TE, Reardon MJ. Autotransplant and advanced techniques for extensive cardiac sarcomas. Op Tech Thorac Cardiovasc Surg. July 31, 2021 [Epub ahead of print].

12. Al Jabbari O, Abu Saleh WK, Patel AP, Igo SR, Reardon MJ. Use of threedimensional models to assist in the resection of malignant cardiac tumors. $J$ Card Surg. 2016;31:581-3. 